\title{
Phonological Awareness Program: A longitudinal study from Preschool to $4^{\text {th }}$ Grade
}

\author{
Inês Ferraz ${ }^{1, a}$, Margarida Pocinho ${ }^{2}$, Alexandra Pereira $^{3}$, and Antónia Pimenta ${ }^{4}$ \\ ${ }^{1}$ PhD Student, University of Minho, Institute of Education, 4704-553 Braga, Portugal \\ ${ }^{2}$ Professor, University of Madeira, Department of Arts and Humanities, 9000-082 Funchal, Portugal \\ ${ }^{3}$ Rochinha's Kindergarten Teacher, 9060-082 Funchal, Portugal \\ ${ }^{4}$ Rochinha's Kindergarten Director, 9060-082 Funchal, Portugal
}

\begin{abstract}
This study aims to evaluate the effect of phonological awareness training program in preschool performance of 256 children in Funchal, Portugal. This is a longitudinal study from preschool (2005) to $4^{\text {th }}$ grade (2011). It has an experimental design. The sample includes an Experimental Group (132 children) and a Control group (124 children). We pretend to answer the following research question: To what degree does training children in phonological awareness as early as preschool have short-term and longterm effects on the evolution of students' competencies and disciplinary knowledge? A first evaluation done in 2006 on the effects of this program at the end of preschool education revealed that the Experimental Group presented significant improvements when compared to the Control Group on the considered dimensions. In 2011, the Experimental Group presented Math National Test higher significant results when compared to the Control Group. The Experimental Group's Portuguese National Test presented better results than the Control Group one, but not significantly. This seems to indicate that Phonological Awareness Program can bring benefits and prevent long-term math school failure.
\end{abstract}

\section{Introduction}

The acquisition of reading and writing is considered highly complex. These skills are a prerequisite for communication and social inclusion and also indicate individuals' linguistic and cognitive abilities. The Portuguese National Assessment Tests Test results, performed by the $4^{\text {th }}$ grade primary school students, according to data provided by the Office of Educational Assessment of the Portuguese Ministry of Education for the report of PISA (Program for International Student Assessment) in 2006, reveal a poor performance of Portuguese children in tasks such as reading and writing. So it is considered urgent to create strategies that promote the acquisition and development of these skills.

Data from PIRLS (Progress in International Reading Literacy Study), in 2011, also show that success in reading is linked to the knowledge of the sound of letters of the alphabet, which is provided by phonological awareness. Phonological awareness is the ability to listen, to recognize, and manipulate

\footnotetext{
a e-mail: inesprferraz@gmail.com
}

This is an Open Access article distributed under the terms of the Creative Commons Attribution License 4.0, which permits unrestricted use, distribution, and reproduction in any medium, provided the original work is properly cited. 
sounds of language. This ability includes rhymes, syllables, onsets and rimes, and individual sounds or phonemes. To develop phonological awareness skills, we need to begin with more general types of listening skills and bigger pieces of language and gradually move to smaller and smaller sounds until children learn to listen and use individual sounds of language.

Some authors defend that phonological awareness is a skill that allows consciously to reflect on and to manipulate the sounds that make up speech. This ability is subdivided into consciousness: syllabic, and phonemic [1]. To the acquisition of reading and speech is crucial to understand the alphabetic code. To read and write is necessary to recognize that words can be divided into syllables and phonemes. Therefore phonological awareness is considered a prerequisite for learning to read and write, so you can make the correspondence between graphemes and phonemes is necessary to have a minimum of phonological sensitivity [2].

In the literature it is stated that children with a well-developed phonological awareness in preschool are more likely to become good readers, so it is crucial to bet on a preventive intervention in order that all children succeed in school. In several studies and programs developed with the purpose to educate and to tutor good readers, the idea that phonological awareness is crucial to children's school success is evident.

Some authors argue that the main concern of the school must go through the promotion of the development of phonic sensitivity aspects, in order to develop phonological awareness, since "the alphabetic code appeals for a cognitive ability that most children do not have when they are entering school, namely, the ability to consciously identify and isolate the sounds of spoken speech" (p. 7) [1].

The investigation of the relationship between metalinguistic awareness and literacy is more and more frequent. The number of studies on this topic has substantially increased, since one of the factors defined in the technical literature as crucial in the process of language acquisition is metalinguistic awareness. Metalinguistic awareness has several abilities that help in learning how to read and to write: phonological awareness, morphological awareness, and syntactic awareness. In the literature phonological awareness is described like the ability to recognize rhymes, to identify, to reconstruct, to segment, and to manipulate the sounds in spoken words. Morphological awareness is defined as an ability that reflects an intentional manipulation of the constituents of sentences. Syntactic awareness manifests itself in the ability to assess the grammaticality $[3,4]$. The educator must have the perception that the emergence of syntactic awareness is acquired later than the phonological or morphological ones, because the child has difficulty in distancing himself/herself from the contents of the phrase in order to being able to focus his/her attention on the its formal aspects [5].

Phonological awareness is the most studied competence, and the research that has been carried out shows the importance of this skill for the acquisition of reading and writing competences. We saw in literature that when a child begins to master spoken language he/she also begins to give attention to the meaning and not to the sound of words, but as they grow their linguistic field also grows and they begin to recognize that words are made up of sounds that could be isolated and manipulated. Phonological awareness is the ability to perceive sounds regardless of their meanings [2]. Phonological awareness develops gradually as the child recognizes syllables, and phonemes. When children could separate items, they develop the awareness of the sound structure of language and this awareness can be divided into two levels: awareness supraphonemic - which refers to the awareness of syllables, rhymes, alliteration, and words, and phonemic awareness - which refers to consciousness that language is composed of small phonemes [6-8]. Some authors [9-11] show that the abilities of syllabic analysis and supraphonemics are performed before the manipulation of the phoneme. They argue that syllabic awareness develops spontaneously in children in preschool age and in the illiterate, that is to say that this skill does not require an explicit teaching, because it develops naturally. Numerous works have showed that, cognitively, the unit "syllable" was easier to extract for young children, in comparison with the unit "phoneme" [2]. However, to these authors, the same is not true for phonemic awareness, since it develops in parallel with explicit instruction and depends on it. When children show difficulties 
in phonological awareness tasks, it derives from the degree of abstraction of the sound segments in analysis and defines phonemes as the most abstract units in speech.

Some authors show that phonological awareness and phonemic awareness are different. The phonological awareness corresponds to the explicit knowledge of the phonetic units of speech, while the phonemic awareness is more comprehensive because in addition to phonemic awareness covers also the units large than phonemes: words and syllables [12]. Phonemic awareness is a complex phonological skill and requires a higher level of abstraction, so it should be developed at a later stage of the syllabic awareness [13].

Phonological awareness in its different dimensions allows you to make predictions with a high degree of reliability on the child's success in the learning of reading and writing. We know that the child must realize that the spelling does not necessarily have a direct relation with the phonology, because a letter can have different sounds and a phoneme can be represented by different graphemes.

According to some authors "The development of phonological awareness is an important precursor to learning reading and writing" (p. 31) and difficulties in acquiring reading and writing skills are associated with the performance in phonological awareness tasks [1]. However even if much previous scholarship has established a link between the level of phonological awareness and learning reading (decoding), research has shown that learning reading and writing was dependent on several skills and knowledge and rich experiences: oral skills (level of the vocabulary, phonological awareness) and written skills (knowledge of letters, knowledge of certain conventions) [14]. The work that is developed at the school, early on, in the area of phonological awareness will promote the school success by preventing failure in the reading and writing tasks.

Phonological awareness is a prerequisite for learning to read and write in Portuguese, so that you can make a systematic correspondence between graphemes and phonemes it is necessary to have a minimum of phonological sensitivity [15]. Children learn to speak and listen naturally, and use the phonological elements of language unconsciously. The development of linguistic awareness involves a gradual shift in the child's attention from the meaning to the structure of language [14]. It is necessary to note that phonological awareness and learning to read maintain an interactive relationship: a minimum level of phonological awareness supports the entrance to reading, and reading experiences amplify the level of phonological awareness. The low skills in phonological awareness have been associated with difficulties in understanding the nature of the relationship between letters and sounds [16]. Today it is known that it is possible to prevent disturbances of reading and writing through the early development of essential language skills for literacy.

Phonological awareness must be trained prior to the acquisition of literacy and language awareness activities should be promoted from kindergarten-schools, since they are crucial activities for the development of oral and written language [6]. Teacher must be aware of what phonological awareness is and how to use it in the classroom [13]. The students should reflect on the words and treat them independently from the information they provide. This author says that phonological awareness needs to be worked in the classroom, in order to help in learning and arising from the questions made by the children.

In 2010 the Portuguese Ministry of Education through the National Program for Teaching Portuguese Language and the General Directorate for the Innovation and Curriculum Development warned preschool and primary school teachers to the need to train the student's phonological awareness before and during the learning of the alphabetical code. In order to promote continuity between education cycles they launched the "Learning Goals", final and intermediate, relating with the different areas and subjects of preschool and of the first cycles of school, the first three cycles of basic education. These goals are created to promote teaching and learning quality and it is intended that teachers analyze the targets of the previous and subsequent cycles in order to be able to work in a line of continuity of the learning that is undertaken by pupils [17]. Therefore, what is intended is that preschool creates the conditions necessary for children to succeed in their learning and to allow them to recognize their 
Table 1. Sample distribution.

\begin{tabular}{|c|c|c|c|c|c|c|c|c|c|}
\hline & \multicolumn{4}{|c|}{2005} & & \multicolumn{4}{|c|}{2011} \\
\hline & \multicolumn{2}{|c|}{$\begin{array}{l}\text { Control } \\
\text { Group }\end{array}$} & \multicolumn{2}{|c|}{$\begin{array}{l}\text { Experimental } \\
\text { Group }\end{array}$} & & \multicolumn{2}{|c|}{$\begin{array}{l}\text { Control } \\
\text { Group }\end{array}$} & \multicolumn{2}{|c|}{$\begin{array}{l}\text { Experimental } \\
\text { Group }\end{array}$} \\
\hline & $\mathrm{N}$ & $\%$ & $\mathrm{~N}$ & $\%$ & & $\mathrm{~N}$ & $\%$ & $\mathrm{~N}$ & $\%$ \\
\hline GENDER & & & & & GENDER & & & & \\
\hline Female & 57 & 45.96 & 64 & 48.48 & Female & 57 & 54.8 & 61 & 52.6 \\
\hline Male & 67 & 54.04 & 68 & 51.52 & Male & 47 & 45.2 & 55 & 47.4 \\
\hline AGE & & & & & AGE & & & & \\
\hline 5 years and half & 93 & 75.00 & 89 & 67.42 & 9 years and half & 79 & 75.9 & 79 & 68.1 \\
\hline 6 years & 31 & 25.00 & 43 & 32.58 & 10 years & 25 & 24.1 & 37 & 31.9 \\
\hline
\end{tabular}

own potential and progress. The Curriculum Guidelines for Preschool Education, Portuguese Ministry of Education in 1997 stated that "The various contexts of preschool education are, thus, spaces where children construct their learning" (p. 18) [18].

It is urgent that the school is aware of the function that phonological awareness should have on learning and on the academic success of students. The school should focus on teaching learning strategies, that is to say, to teach students how to learn and how to think (cognitive training). Teaching to learn and to think is not specific to certain disciplines, but applies to any school curriculum [19].

Individuals with reading difficulties have alterations in information processing and, this processing is based on language and cognitive aspects, the understanding of the problems listed and Mathematical calculations, requiring a match mental lexicon and a numerical representation, which ultimately compromise the results in Mathematics [20].

The aims of this study are: (1) to diagnose phonological awareness levels in preschool children; (2) to analyse the effectiveness of a phonological awareness program in preschool children; (3) and to study the effects of a phonological awareness program in $4^{\text {th }}$ grade elementary school (Portuguese Language National Assessment).

\section{Research question}

To what degree does training children in phonological awareness as early as preschool have short-term and long-term effects on the evolution of students' competencies and disciplinary knowledge?

\section{Method}

This is a longitudinal study from preschool (2005) to $4^{\text {th }}$ grade (2011). It has an experimental design. The attained results led to the establishment of two homogeneous groups (Experimental and Control Group). An intervention program was applied to the Experimental Group. We use PASW version 19 program to do the statistical analysis.

\subsection{Participants}

In 2005 the sample included 256 preschool children: Experimental Group (132 children) and a Control Group (124 children). In 2011 the sample included $2214^{\text {th }}$ grade elementary school children: Experimental Group (117 children) and a Control Group (104 children).

This is our sample distribution with some female some male. The majority of our parents have poor qualifications; only a quarter have a university college degree, and with low socioeconomic environment. 

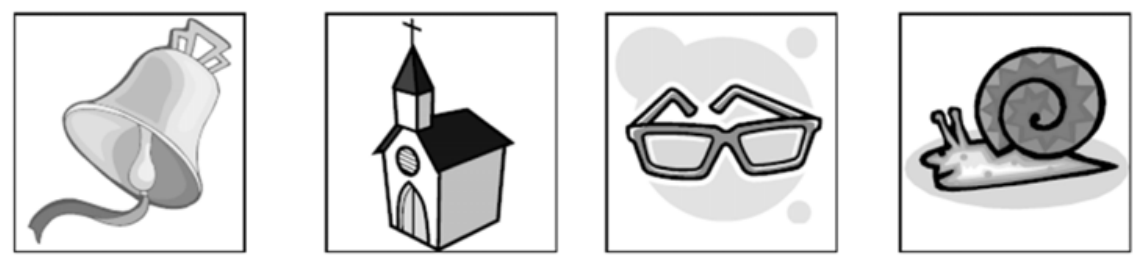

Figure 1. Example of a test: "Repeat every word after me [sino (bell)/igreja (church)/óculos (glasses)/caracol (snail)]. Now point out the figure that begins with the sound i".

\subsection{Instruments}

The instrument that we use to evaluate the children phonological awareness was The Evaluation Test of Phonological Awareness (in Portuguese: PACF). This program was designed to Portuguese language which includes syllabic, intra syllabic and phonemic awareness.

The test was administered orally and individually to each child in a room without noise, with an approximate duration of 45 minutes. It is important to point out on the fact that this test was applied by the examiner to children who were part of the sample. The choice of children who underwent this test was random.

Pre and Post-test structure: Test I - Lexical segmentation (8 items); Test II - To separate syllables and phonemes (6 items); Test III - To omit syllables and phonemes (14 items); Test IV - To identify if the first syllable and/or the last syllable matches with the same syllable in another word (20 items); Test V - To count syllables (10 items); Test VI - To identify and say a word divided into a sequence of syllables (5 items); Test VII - To omit syllables (10 items).

The internal consistence of Evaluation Test of Phonological Awarenessis: Alpha de Cronbach of 0.95 (Study 2005) and Alpha de Cronbach of 0.94 (Study 2011).

\section{Example Test II - To separate syllables and phonemes (6 items):}

The examiner must ensure that the child correctly identifies the name of each picture. Otherwise, it must tell the correct name. "I will show you some pictures. Look at these pictures. Are you going to tell me the name of each picture".

The phonological awareness training program was applied to the experimental group with individual testing. This program has eight sessions of intervention, in order to stimulate phonological awareness. Each session lasted approximately 30 minutes; the duration could vary according with the predisposition that children demonstrated throughout each game. This group was divided into small groups of three to four elements or individually. The examiner sat in front of children so that they could have easy access to the figures which were the supporting material and that he could grasp what the response formulated was.

The eight intervention sessions had the supervision and guidance of the examiner. Each session contains instructions on the procedures to be used in each of the training games and it is composed of three distinct activities that follow a line of growth of the degree of difficulty, so you have the simplest activities firstly which later evolve into more complex ones. Some of these training sessions are supported by a visual aid (picture cards) that are properly identified. The tasks of this program are: Lexical segmentation; Separate syllables and phonemes; Omit syllables and phonemes; Identify if the first syllable and/or the last syllable matches with the same syllable in another; Count syllables; Identify and say a word divided into a sequence of syllables; and Omit syllables. Phonological awareness training program was applied to the experimental group. 


\section{SHS Web of Conferences}

Table 2. Differences between Experimental Group and Control Group (pre-test to post-test).

\begin{tabular}{|l|l|l|l|l|}
\hline & Group & Mean & Study Deviation & Std. Error Mean \\
\hline \multirow{2}{*}{ Pre-test (Form A) } & Experimental & 46.0530 & 8.62299 & 0.75053 \\
\cline { 2 - 5 } & Control & 46.0403 & 9.21063 & 0.82714 \\
\hline \multirow{2}{*}{ Post-test (Form B) } & Experimental & 60.4252 & 8.91184 & 0.79080 \\
\cline { 2 - 5 } & Control & 54.5167 & 10.80459 & 0.98632 \\
\hline
\end{tabular}

\subsection{Procedures}

All procedures required to conduct an ethical research were followed. We apply the Evaluation Test of Phonological Awareness in 2005. The institutions were contacted before the beginning of the study. In preschool, the application of the test was carried in the beginning of the school year (pre-test) and in the end of the school year (post-test).

The Experimental Group was submitted to the phonological awareness training in 2005. With regard to data collection, the data was obtained between the months of October of 2005 and May of 2006.

This research includes the following phases: (1) application of the pre-test (Evaluation Test of Phonological Awareness - Form A) to the Experimental Group, and Control Group; (2) implementing the Phonological Awareness Training Program to the Experimental Group; (3) implementation of the post-test (Evaluation Test of Phonological Awareness - Form B) to Control Group and Experimental Group.

The pre-test was administered orally and individually to each child in a room that was not the activities room and devoid of noise, with an approximate duration of 45 minutes. The choice of children who underwent this test was random.

The Experimental Group was subject to eight sessions of intervention, in order to stimulate phonological awareness. Each session lasted approximately 30 minutes. Each session contains instructions on the procedures to be used in each of the training games and some of these training sessions are supported by a visual aid (picture cards) that are properly identified. Considering that this program consisted of eight sessions, it was decided that each session corresponded to one week. The duration of this program was two months.

To ensure that children have not memorized the activities in the training program, about two months after its implementation we applied the post-test to the children of Experimental Group. The posttest was applied too in children who were part of the Control Group. The Experimental Group and Control Group teachers have the same socio-demographic and professional features. They apply the same method of teaching. The same procedures applied in the pre-test were carefully used in the posttest.

At the end of $4^{\text {th }}$ grade elementary school (2011) we analyse the results of Portuguese National Assessment Tests achieved by all the participants.

\section{Results}

\section{$1^{\text {st }}$ Validation of Intervention program (2005):}

There are no statistically differences according gender and parents academic qualifications, although girls usually have higher scores than boys.

In the Pre-test, there are no differences between Experimental Group and Control Group $(\mathrm{t}=0,11$; g.l. $=254 ; \mathrm{p}=0,991)$, but in the Post-test there are significant differences between Experimental Group and Control Group ( $\mathrm{t}=4$, 674; g.l. $=254 ; \mathrm{p}<0.001)$, with higher scores in Experimental Group (Table 2). 
Table 3. Differences between Experimental Group and Control Group in the Portuguese National Assessment Tests.

\begin{tabular}{|l|l|l|l|}
\hline Group & Assessment & Mean & Std. Error Mean \\
\hline \multirow{2}{*}{ Experimental } & Portuguese & 3.83 & 0.726 \\
\cline { 2 - 4 } & Maths & 3.68 & 1.043 \\
\hline \multirow{2}{*}{ Control } & Portuguese & 3.71 & 0.759 \\
\cline { 2 - 4 } & Maths & 3.50 & 0.948 \\
\hline
\end{tabular}

Longitudinal Study (2005-2011) $4^{\text {th }}$ grade elementary school:

In 2011 we analyse Portuguese National Assessment Tests results achieved by children at the end of the $4^{\text {th }}$ grade. There are statistically significant differences between Experimental Group and Control Group in the Math test $(\mathrm{p}=0.003)$.

Mean Experimental Group ( $\mathrm{M}=3.83$, 3.68) were statistically higher than the Control Group $(\mathrm{M}=3.71,3.50)$. There are no statistically significant differences between Experimental Group and Control Group in the Portuguese National Assessment Tests, although Experimental Group presents higher scores than Control Group (Table 3).

In the Portuguese Language National Assessment there's no statistically significant differences by gender $(\mathrm{p}>.05)$, however the females $(\mathrm{M}=3.91)$ had higher average compared to males $(\mathrm{M}=3.65)$ in the Portuguese language test.

In Math's test males $(M=3.73)$ averaged higher than females $(M=3.60)$.

\section{Discussion}

The Ministry of Education in 2010 enunciated a set of "Learning Goals" for preschool that specifically included the development of phonological awareness. The concern showed by the people responsible for the Portuguese educational policy shows the importance of this pre-requisite in successfully concluding primary school. According to the data obtained in the Progress in International Reading Literacy Study the factor that best predicts the academic success of children is related to the learning of letters [21]. The knowledge of the alphabet is a feature of literacy and the main objective of preschool teaching and early educative intervention is to facilitate its development [22].

A study in 2005 with 256 preschool children proved that an intervention program increases phonological awareness, because Evaluation Test of Phonological Awareness results indicate a growth of the phonological awareness levels after the post-test.

The results in 2011 proved that the training of phonological awareness in preschool influences positively the acquisition of knowledge in Math's in the elementary school. However it is possible to claim that the differences between both groups in the $4^{\text {th }}$ year of the primary school are attributable to other factors that could have influenced this differences [23]. Although the teaching practices are the same but we don't know exactly how they have stimulated the children. This fact maybe influence the results.

It was found that there were statistically significant differences in Math test measurement between Experimental Group and Control Group, which shows that the training of phonological awareness in preschool influences positively in the acquisition of knowledge in Mathematics which can be proved, also, in other study [7], where proves a correlation between phonological awareness and grades of different disciplines, including Mathematics. Another study [24] shows that children who have poor performance phonological awareness have underperformed in Mathematics.

In conclusion, this study found that children who had a well-developed phonological awareness had more ease in acquiring knowledge in Math showing that the practice of this skill in preschool positively influences the acquisition of knowledge. 
The early teaching of metalinguistic skills might be a contribution to prevent reading and writing failure and promoting the quality of preschool education. Given that phonological awareness is a good predictor of success in reading and writing, their evaluation in the transition from preschool to primary school is fundamental [25], as it allows you to check the difficulties presented by children and allows teachers to plan strategies to facilitate the acquisition of these skills. Knowing that the training of this metalinguistic ability allows you to prevent children's difficulties in reading and writing, we feel that it should be implemented in all institutions of preschool education.

\section{Final remarks}

Scores assessed with the Evaluation Test of Phonological Awareness indicate a growth of the phonological awareness levels after the post-test at the end of preschool and in $4^{\text {th }}$ grade of elementary school.

Results sustain that intervention programs such as this one can improve pre-reader children metalinguistic competences and also improve reading and writing skills in future. As a consequence, maybe it can prevent school failure too.

\section{References}

[1] Freitas, M.J., Alves, D., \& Costa, T. (2007). O conhecimento da língua: desenvolver a consciência fonológica. [Knowledge of language: developing phonological awareness]. General directorate for the innovation and curriculum development. Lisboa: Ministério da Educação

[2] Sim-Sim, I. (2006). Ler e ensinar a ler. [Read and teaching to read]. Lisboa: Edições Asa

[3] Mota, M.P., \& Silva, K.C. (2007). Consciência morfológica e desenvolvimento ortográfico: Um estudo exploratório. [Morphological awareness and orthographic development: a exploratory study]. Revista Psicologia em Pesquisa-UFJF, 1(2), 86-92

[4] Silva, M.C. (2007). Atividades de consciência linguística no Jardim-de-Infância: O quê, como e para quê? [Language awareness activities in kindergarten: What, how and for what?]. Revista Cadernos de Estudo, 6, 43-52

[5] Demont, E. \& Gombert, J.E. (1996). Phonological awareness as a predictor of recoding skills and syntactic awareness as a predictor of comprehension skills. British Journal of Educational Psychology, 66 (3), 315-332. doi: 10.1111/j.2044-8279.1996.tb01200.x

[6] Adams, M., Foorman, B., Lundberg, I., \& Beeler, T. (2006). Consciência fonológica em crianças pequenas. [Phonemic awareness in young children: A classroom curriculum]. Porto Alegre: Artmed

[7] Capovilla, A.G., Dias, N.M., \& Montiel, J.M. (2007). Desenvolvimento dos componentes da consciência fonológica no ensino fundamental e correlação com nota escolar. [Development of phonological awareness components in elementary school and relationship to school performance]. Revista Psico-USF, 12(1), 55-64

[8] Nunes, C., Frota, S., \& Mousinho, R. (2009). Consciência fonológica e o processo de aprendizagem de leitura e escrita: Implicações teóricas para o embasamento da prática fonoaudiológica. [Phonological awareness and the process of learning reading and writing: Theoretical implications for the basement of the speech-language pathologist practice]. Revista CEFAC, 11(2), 207-212

[9] Lima, R.M., \& Colaço, C.S. (2010). Falantes conscientes, leitores competentes. [Speakers conscious, competent readers]. Revista Exedra, 9, 245-256

[10] Lourenço, C., \& Martins, M.A. (2010). Evolução da linguagem escrita no pré-escolar. [Evolution of written language in preschool]. Actas do VII Simpósio Nacional de Investigação em Psicologia, Universidade do Minho, 2749-2762 
[11] Strattman, K., \& Hodson, B.W. (2005). Variables that influence decoding and spelling in beginning readers. Child Language Teaching and Therapy, 21(2), 165-190. doi: 10.1191/0265659005ct287oa

[12] Silva, A.C. (2003). Até à descoberta do princípio alfabético. [Until the discovery of the alphabetic principle]. Coimbra: Fundação Calouste Gulbenkian

[13] Correia, I.S. (2010). "Isso não Soa Bem”: A Consciência Fonológica do lado de Lá Reflexão em torno exercícios de Consciência Fonológica no Primeiro Ciclo. Actas do I Encontro Internacional do Ensino de Língua Portuguesa. ["That does not sounds good": The phonological awareness over there: Reflection about phonological awareness exercises in the first cycle]. Revista Exedra, 9, 119-132

[14] Elbro, C., \& Scarborough, H.S. (2004). Early Identification. In T. Nunes \& P. Bryant (Eds.), Handbook of Children's Literacy (pp. 339-359). Dordrecht: Kluwer Academic Publishers

[15] Santamaria, V., Leitão, P., \& Assencio-Ferreira, V. (2004). A consciência fonológica no processo de alfabetização. [Phonological awareness in literacy process]. Revista CEFAC, 6(3), 237-241

[16] Smith, G.C. (2010). Phonological awareness and word recognition during reading in children with autism. Communication Disorders Quarterly, 31(2), 67-85

[17] Sim-Sim, I., Duarte, C., Duarte, I., Barbeiro, L., \& Pereira, L. (2010). Metas de aprendizagem. [Learning goals]. Portuguese Ministry of Education: General Directorate for the Innovation and Curriculum Development

[18] Portuguese Ministry of Education (1997). Orientações curriculares para a educação préescolar. [The Portuguese curriculum guidelines for pre-school education]. Lisboa: Ministério da Educação

[19] Pocinho, M., \& Canavarro, J.M. (2009). Sucesso escolar e estratégias de compreensão verbal: Como compreender melhor as matérias das aulas? [Educational attainment and verbal comprehension strategies: How to better understand the materials of classes?]. Viseu: Edições Pedago

[20] Geary, D. (2004). Mathematics and Learning Disabilities. Journal of Learning Disabilities, 37 (1), 4-15

[21] Araújo, L. (2011, June). Are differences in reading achievement in PIRLS related to curriculum and instructional practices? 8th Bi-annual Conference of International Association for the Improvement of Mother Tongue Education, Hildesheim, Germany

[22] Piasta, S.B., \& Wagner, R.K. (2010). Developing early literacy skills: A metaanalysis of alphabet learning and instruction. Reading Research Quarterly, 45(1), 8-38

[23] O'Connor, M., Arnott, W., McIntosh, B. \& Dobb, B. (2009). Phonological awareness and language intervention in preschoolers from low-economic backgrounds: A longitudinal intervention. British Journal of Developmental Psychology, 27 (4), 767-782

[24] Capellini, S., Padula, N., Santos, L., Lourenceti, M., Carrenho, E., \& Ribeiro, L. (2007). Desempenho em consciência fonológica, memória operacional, leitura e escrita na dislexia familial. [Performance in phonological awareness, memory, reading and writing in dyslexia]. PróFono Revista de Atualização Científica, 20(19), 374-380

[25] Goswami, U. (2000). Phonological and lexical processes. In M.L. Kamil, P.B. Mosenthal, P.D. Pearson, R. Barr (Eds), Handbook of reading research (pp. 251-267), Vol. III., Mahwah, NJ, US: Lawrence Erlbaum Associates Publishers 